\title{
Waste Management Regulation in Cameroon: A Curse or Blessing?
}

\author{
Fonja Julius Achu*
}

Ph.D. (University of Yaoundé II) Department of English Law, Faculty of Laws and Political Science, University of Yaoundé II, BP 1365 Yaoundé, Soa, Cameroon

\author{
DOI: $\underline{10.36348 / \text { sijlcj.2019.v02i11.008 }}$ \\ | Received: 21.10.2019 | Accepted: 28.10.2019| Published: 26.11.2019 \\ *Corresponding author: Fonja Julius Achu
}

\section{Abstract}

Due to the gaps in the law and the weaknesses of the available ones individuals, hospitals and industries dump their waste anyhow and anyway in Cameroon, This uncultured behaviour leads to pollution of the air, water and land,. The ramification of this pollution is diseases on man animal and plants. This paper investigates why the law regulating in waste management is not enforced and the lacunae of the same. The paper does so through a reading of records mainly from documentary and internet search. The data does collected constitute the sources from which the law is drawn ,stated and analysed in the light of the stated aim of the paper. The results inter alia show that the law that regulates waste management are not well enforced. The said results also show the lacunae in the laws and equally high light the limitation of the available laws regulating waste management in Cameroon. The results are significant as they expose gaps in the current laws regulating waste management and conclude with suggestions on where the law should go.

Keywords: Waste, management, pollution, recycling, incineration, re-use, open dumps, landfill, duty of care.

Copyright @ 2019: This is an open-access article distributed under the terms of the Creative Commons Attribution license which permits unrestricted use, distribution, and reproduction in any medium for non-commercial use (NonCommercial, or CC-BY-NC) provided the original author and source are credited.

\section{INTRODUCTION}

The legal control of waste in the world offers a fascinating case study of different regulating forms and mechanisms that can be used to address one of the major by- products of industrialisation and our way of life: the need for waste disposal. Developing different strategies of waste management and control has been one of the most daunting challenges facing Cameroon.

Human beings generate vast amounts of unwanted stuff daily, because the production of waste is a natural consequence of life in both human ecosystems and industries. As human consumption increase, so does waste. The places to dispose of our trash are becoming more and more scare as the contents have become increasingly unpleasant and dangerous. Given that most developing countries do not want it in their backyards, it often ends up in those of the poorest and least powerful countries around the world $\left[{ }^{1}\right]$.

\section{What is "Waste"}

It has not been easy to give a comprehensive and popularity accepted definition of waste because most of the problems associated with defining waste

${ }^{1}$ Bell and Bell (1994 Environmental Law: the law and police Relating to the Protection of Environment. $4^{\text {th }}$ Ed London, Blackstone press ltd. P40 adequately stem from the fact that it is not necessarily synonymous with actual pollution or harm. Consequently there are many "grey areas" which can lead to uncertainty and confusion. These include such things as whether something which can be re-used but which is discarded should be classified as waste (for example electrical equipment which is placed into a dustbin but which functions perfectly) whether something which is not wanted by one person (and is therefore gotten rid of ) but valued by another (which is evidenced by the fact that they will "buy" it) can be waste $\left[{ }^{2}\right]$ or finally whether a residue or a by-product from industrial process which can be used as a replacement for a raw material should be classified as waste. The consequences of a material or substance being determined to be waste are important. Deciding whether a material or substance is waste is probably one of the most complex areas of environmental law, However, this does not mean there are no acceptable definitions of waste. The most comprehensive one will be discussed. The Environmental code $\left[{ }^{3}\right]$ of Cameroon

\footnotetext{
${ }^{2}$ Case in point are second hand goods from Europe and America which have proliferated almost every where in Cameroon .They are called second hand goods in Cameroon but are rejected or waste articles from overseas.

${ }^{3}$ Law No $96 / 12$ of $5^{\text {th }}$ August relating to environmental management
} 
defines waste in its section 4(c) as "any residue from a production, process or utilisation processing or utilisation process, any substance or material produced or, more generally, any moveable and immovable goods abandon or intents to be abandoned".

The European Court of Justice in 1990 defines waste as "any substance or object which the holder "discards" or intends or is required to discard and which falls into one of the categories set out in Annex I to the amended Directive $\left[{ }^{4}\right]$. In other words it defines waste as "substance or object which the holder disposes of or is required to dispose of". This definition has been upheld in two cases appearing before the European court of justice Vassesso and Zanetti $\left[^{5}\right]$.

\section{Why does Waste Need Regulating?}

Waste requires regulation simply because they are unwanted. A waste and a raw material may have equivalent hazardous properties. But whilst there is an economic incentive to use the raw material efficiently and carefully, there is not the same imperative with the waste. Indeed, the economic imperative is to dispose of it as cheaply and as quickly as possible, and without taking care to ensure that its hazardous properties do not cause harm to the environment. It is not only through disposal that waste can harm the environment. Harm can also arise when waste is stored, transported or treated. Regulation therefore needs to extend more widely than to disposed practices.

It is known that available total ice free land area in the world is approximately 13.4 billion hectares $\left.{ }^{6}\right]$. Out of this figure only about $3.2\left[^{7}\right]$ billion hectares or 24 per cent $\left[{ }^{8}\right]$ are potentially arable or productive. What this means is that the arable land now available should be saved from degradation and misuse. Al Gore $\left[{ }^{9}\right]$ in his book $\left[{ }^{10}\right]$ stated that "one of the clearest signs that our relationship to the global environment is in severe crises is the flood of garbage spilling out of our cities and factories" he opines that what some have called the "throw-away society" has been based on the assumption that endless resources will allow us to produce an endless supply of goods and that bottomless receptacles will allow us to dispose of an endless stream of waste. This habit cannot be sustained any more. We appear, if care is not taken by all concerned, to be drowning in that stream. We are now running out of

\footnotetext{
${ }^{4}$ It was held in these case that, matters is waste to get rid of it

${ }^{5}$ (c-206/88andc-207/88\} |1990\} ECR1-1461

${ }^{6}$ Simpson S and Fagbohun, O (1998) Environmental Law and Policy $1^{\text {st }}$ Ed. Law centre university of Lagos p. 62 ${ }^{7}$ Ibid

${ }^{8}$ ibid

${ }^{9}$ Former vice present of the United State of America then senator.

${ }^{10}$ Gore Al (1992) Earth in the Balance, Ecology and Human spirit $1^{\text {st }}$ Ed Houghton Mifflin company, Boston USA. P.30
}

ways to dispose of our waste in a manner that keeps it out of either sight or mind $\left[{ }^{11}\right]$.

Carson $\left[{ }^{12}\right]$, thirty years of earlier than senator Al Gore, had raised a genuine alarm on the threat human activities pose to the environment. However, in the environmentally less-conscious era $\left[{ }^{13}\right]$ human population and the quantities of waste generated to the environment were minimal. The feeling everywhere, citing experience in Yaoundé and Douala is that we are disconcerted, even offended, when the huge quantities of waste we thought had been safely disposed of suddenly demand our attention: as land fills overflow, incinerators foul the air, and neighbouring communities and states attempt to dump their overflow problem on us.

The inability of the individual and the state to exercise adequate discipline and control over drastic changes in the environment often gives rise to indiscriminate dumping of waste which destroys the ecosystem. This leads to a complete transformation of the environment. This the "green grass" of the surrounding that one used to know, becomes a barren field. The unnecessary destruction of the environment gives rise to the need for control. To control require forceful acquisition of personal discipline, neighbouring discipline backed by adequate and workable intricate legal process.

\section{Classification of Wastes}

The 1996 Environmental code does not classify waste but this does not mean waste is not classified. Waste can first of all be classified according to its viscosity or state. By this we mean whether it is in the liquid or solid state. Solid waste include waste such as peeling used cartoon, old cars fridges, broken bottles and liquid waste include waste from septic tanks both kitchen sinks amongst many others.

Waste can further be classified according to municipal or urban and industrial. Municipal waste is composed of all waste which is generated by shops, households, and offices. The generation of municipal waste is closely related to levels of industrialization and income per day $\left[{ }^{14}\right]$. Non-municipal hazardous or toxic waste tends to be categorised by reference to its source (industrial mining or agricultural) and in relation to the applicable rules its characteristics (non-hazardous, toxic and radioactive).

\footnotetext{
${ }^{11}$ The amount of waste generated in producing everyday products is $1.5 \mathrm{~kg}$ for a toothbrush, $75 \mathrm{~kg}$ for a mobile phone and $1.500 \mathrm{~kg}$ for a personal computer-thus is a conclusion of Wuppertal institute as quoted in European Commission communication com(301 find.

${ }^{12}$ Carson, R (1963) Silent springs $1^{\text {st }}$ Ed, Houghton Muffling Comp. Boston USA p 21

${ }^{13}$ This is about 50years ago.

${ }^{14}$ UNEP Environmental Data Report $19913^{\text {rd }}$ Ed p. 335
} 
Lastly, the EPA, 1990, classified waste into two: namely special waste and controller waste. Special waste is waste which "may be dangerous or difficult to treat, keep or dispose of, that special provision is required to deal with it $\left[{ }^{15}\right]$. On the other hand, controlled waste is that which is subject to control apart from special waste. This includes households, industrial and commercial waste $\left[{ }^{16}\right]$.

\section{Types of Waste}

The 1996 Environmental code does not distinguish the types of waste it only defines it in its article 4(c) but its enabling instrument $\left[{ }^{17}\right]$ does so in its article 2.

\section{Household and Consumer Wastes}

This includes waste from domestic premises, caravan sites, residential homes, educational establishment and nursing homes.

\section{Commercial Wastes}

This is waste from premises used for a trade, business or for recreational purposes.

\section{Industrial Wastes}

This is waste from factory (factors rubbish (public transport facilities such as airports and bus stations and premises used for the provision of public utilities, packing materials, organic waste, acids and article among others.

\section{Mining Wastes}

These are by-products of the extraction process and include top soil, rock and dirt which may be contaminated by metals and coal.

\section{Agricultural Waste}

This comprises of animal slurries silage effluents, tanks washing following pesticide use, and empty plastic packaging.

\section{Hospital Wastes}

This is waste produce by hospital establishments. It includes, used syringes, bandages, cotton, expires medicines, old hospital beds and old hospital equipments.

\section{Demolition and Construction Wastes}

It includes waste which results from demolition and construction sites. It is made up

\footnotetext{
${ }^{15}$ EPA 1990, section 62

${ }^{16}$ EPA 1990, S 75 the control of waste regulations 1992(s.1, 1992. No 558) for licensing matters only the definition under the former law apply and are to be found in the controllers of pollution Art of 1974 s. 30 and the collection and disposal Regulations (31, 1998 no .819)

${ }^{17}$ Decree No 2012/2809 PM of 26 Sept 2012 fixing the conditions to collect, store, transport, recycle treatment and final elimination of waste.
}

principally of old rods, zincs, broken windows, doors, toilet pots, broken blocks and debris.

\section{Litters}

It is the form of waste which is an integral part of a consumer society. It is odds and ends, bits of paper discarded wrappings, bottles and so on, left lying about in a room or public place. Furthermore, it is the straw and dung of a farm yard. The discarded cigarette packet or coke tin in the street which is aesthetically unattractive. An accumulation of such litter can attract rats and constitute a hazard to human health.

\section{Sewage Sludge}

This is foul thick, grease mud or thick oil or grease sewage material carried off sometimes in sewers. That often carried off in sewers is the liquid type while the solid one is dumped in trash cans or on dump sites .This very common in towns such as Douala and Yaounde.

\section{Radioactive Wastes}

It is the product of nuclear power generation, military source, and medical, industrial and university establishments low-level radioactive waste includes contaminated laboratory debris, biological materials and tailings. High level radio active waste includes spent fuel from nuclear power reactors and high liquid and solid residues from reprocessing of spent nuclear fuels.

\section{Causes of Waste Production}

Across the globe man is a product of his environment Cameroon is not an exception to this generally held truism. The whole essence of life is for man to be at peace with his environment but this is not what obtains because man does not use his environment diligently as he is supposed to, this account for the increase of pollution. The causes of the increase of waste and its poor management are many and complex. Theses causes will be discussed in the he paragraphs below.

\section{Development of Spontaneous Housing}

Housing has been one of ma's needs and in towns one of his main problems creating a great deal of incidental social distress $\left[{ }^{18}\right]$ the limitation in meeting with such needs leads to the construction of makeshift accommodation which place the city under stress because temporary stalls and sheds for goods are erected along pavements.

Before the urban renewal campaign was launched in Cameroon in $1999\left[^{19}\right]$ there was complete anarchy in the growth of houses in big towns which

\footnotetext{
${ }^{18}$ Ezeani EO and Elekwe, N.W (2001) Issues in Urbanisation and Urban Administration in Nigeria $1^{\text {st }}$ Ed Jumoe Enterprise Enugu p 187

${ }^{19}$ Guiffo. J.P (2007) le Droit de l'urbanisation et de la construction au Cameroun Edition de 1 ; Essoa p 203
} 
necessitated an immediate intervention from the public sector. Many factors account for this namely rapid population growth in urban centres inadequate registered land $\left[{ }^{20}\right]$ non- respect of legal conditions of occupation of land $\left[{ }^{21}\right]$. Non respect of town planning regulations $\left[{ }^{22}\right]$ and the almost lack of application of sanction against defaulters $\left[{ }^{23}\right]$. In addition, the expropriation of land belonging to the population without adequate compensation contributes to spontaneous housing in urban towns $\left[{ }^{24}\right]$. Most of the residents of these makeshift houses litter the surroundings with dirt because of the congestion of houses. This makes it very difficult to clean or collect the dirt. HYSACAM $\left[{ }^{25}\right]$ operating in these towns finds it difficult to go into some of the narrow streets in these quarters to collect garbage. This is very common in the Douala and Yaounde neighbourhoods. It is common to see waste everywhere in some of these neighbourhoods dominated by makeshift houses, often known as shanty towns or "elobi" quarters $\left[{ }^{26}\right]$.

\section{Mining}

Mining here includes ordinary mining of minerals and quarries. The discovery of mineral in an area means the minerals will someday be exploited. This will normally lead to the destruction of the vegetal life of the area to enable the company of set up its equipment and embark on harvesting the mineral resources $\left[{ }^{27}\right]$ section 45 of the mining code $\left[{ }^{28}\right]$ states that, before a company can carryout mining activities the president of the republic must give his accord . But it must be mentioned here that with regards to quarries it is not what often obtains because most of the small exploiters of stones secretary exploit them without obtaining a licence and quarry permit from the minister of Mines and Industrial Development as stipulated by section 54 (1) of the mining code. This violation of the provisions of the code can only aggravate the increase in waste on the land $\left[{ }^{29}\right]$. However, even where this

\footnotetext{
${ }^{20}$ Decree No 6/165 of 27 April 1976 fixing the conditions for the obtaining of a land certificate as modified by decree No 2005/48 of 16 December 2005

${ }^{21}$ Section 39 of the 2004 law regulating town planning in Cameroon.

${ }^{22}$ Ibid section 107

${ }^{23}$ Ibid section 125

${ }^{24}$ Guiffo, J.P op cit P 2010

${ }^{25}$ HYSACAM is a company hired by the urban councils in some big towns of Cameroon to collect garbage.

${ }^{26}$ This means slum Clarence zone. In Yaoundé such neighbourhoods include Tsinga - Elobi, Mvog ada, Mvog betsi and Briqueteme.

${ }^{27}$ Campbell, B (2004) "relating mining paper in Africa for whose benefit" discussion paper no 26 Nordica Africa institute u Uppsala p. 20

${ }^{28}$ Section 45 of law No ool of 16 April 2011 establishing the mining code. This section of the mining code is supported by section 38 of the 1996 Environmental code

${ }^{29} \mathrm{~A}$ vivid example is seen in the Damas neighbourhood in the
} Yaounde Urban town where a couple of individual exploit and permission is issued to a company or individual to exploit stones or where a mining permit has been obtained waste will still occur for it cannot be avoided $\left[{ }^{30}\right]$. However 37 (1) of the environmental code states that holders of mining permits should rehabilitate the exploited sites. This includes clearing away the waste because rehabilitation cannot be done without clearing the waste. Often this is not done. This accounts for the accumulation of waste in mining sites.

\section{Individuals}

Public toilets do not exist in Yaounde anymore this makes some uncultured people to defecate and urinate in street corners which makes for a very unattractive sight. Furthermore, most individual plying streets in towns dump their waste just any where $\left[{ }^{31}\right]$. Even in some towns where trash cans or baskets are provided by municipal authorities few do bother to use them. The reasons being that people are not aware that these trash cans are kept at streets corners for then to dump refuse into, secondly, the trash cans are few and lastly, the distance between them is too wide $\left[{ }^{32}\right]$. Most important the environmental code is silent on an act of an individual who throws dirt in the streets or on land. Reliance is therefore made on the municipal order enacted by the various local government authorities $\left[{ }^{33}\right]$.

\section{Lack of Urban Sanitation}

Under this sub heading causes of increase in waste such as incorrect elimination of solid waste and liquid waste insufficient drainage systems and the nonrespect of hygiene rule by the population.

\section{Poor Solid Waste Disposal Method}

Solid waste increases with increase in population. Garbage or other organic waste are deposited, stored, discharged or exposed in such a way as to be a potential for the transmission of diseases such places are found in some towns especially around the market areas. In heavily populated areas such as Yaounde and Douala, refuse dumps often get so large that they reduce the road's width. A number of reasons are responsible for the incorrect elimination of solid

split stones into concrete for sale without the permission of the minister of Mines and Industrial Development.

${ }^{30}$ Omarya, B L (2004) “ The mineral industries of Cameroon and cape Verde" World Bank report No 20 P. 17

${ }^{31}$ These wastes include groundnuts roasted and boiled corns. The stick of this eaten corn and groundnut peelings used handkerchiefs are thrown into streets which lead to waste on the streets.

${ }^{32}$ In 2002 the National institute of statistics disclosed that the distance between two waste basket iis 220 metres in the Yaounde urban centre but in Douala it is more then half a kilometre

${ }^{33}$ For example in Yaounde, the government Delegate enacted an article in 2006 forbidding the throwing of waste into rivers or public places. Section I of this arête prohibits the throwing of dirt into water or public place no matter the hours of the day. The order also obtains in its section II that anybody who violets the instrument will be punished yet most people throw dirt in streets and go unpunished. 
waste. For instance, the almost absence of percollection arrangement, efficient treatment of waste well-managed discharge sites and the ineffectiveness of councils which have limited financial and logistic means $\left[{ }^{34}\right]$. Councils have the duty to clean up and collect garbage in all areas of the country $\left[{ }^{35}\right]$. Some councils in big towns have handed over this duty to private companies $\left[{ }^{36}\right]$ but this company is not executing the job well because of lack of sufficient funds to buy many trucks, replace old ones and employ more staff.

\section{Incorrect Evacuation of Liquid Waste}

With regards to the evacuation of liquid waste the problem of infrastructure is posed. Individual infrastructure such as latrines and septic tanks in most towns of Cameroon are less functional because of their poor construction. The law regaling councils $\left[{ }^{37}\right]$ does not indicate the distance from which a septic tank or pit latrine should be built from the house nor does it indicate how the septic tanks and pit latrines should be built. This explains why individual built their septic tanks and latrines any how and any where. When these latrines and septic tanks fill up they spill over and liquid waste pollutes the surrounding land $\left[{ }^{38}\right]$.

\section{Industrial Effluent}

The poorly conceived urbanisation process of many third world cities has brought with it enormous problems of pollution. This is because the problems of water, land, liquid and solid waste pollution have never been properly addressed especially in the emerging metropolis. In the desire to create new jobs and to catch up with the production of goods and services for the teaming population, the government encouraged the mushrooming of different types of industrial establishments once some of the basic promoters were available $\left[{ }^{39}\right]$. This is the case of Douala today Cameroon's economic capital which established commercial or trade contacts with the outside world since the $15^{\text {th }}$ century $\left[{ }^{40}\right]$. It has since then witnessed the emergence and growth of several socio-economic activities and industries which have served as pull factors that have drawn in a large dynamic hinterland

\footnotetext{
${ }^{34}$ Dynamique locales No. 001, October- December 2011, p.10

${ }^{35}$ See section 16 of Law No 2004/018 of 22 July $7^{\text {th }} 2004$

${ }^{36}$ The company is called HYSACAM which has been hired by councils to clean and collect garbage.

${ }^{37}$ Law No 2004/018 of 22July 2004

${ }^{38}$ This is common at he Biyem- Assi neighbourhood in the Yaounde urban town where in areas called "Carrefour Kaka" which in popular understanding means "excreta round about" because of the constant spill over of the septic tank in that area

${ }^{39}$ The president of the Republic of Cameroon has created a new ministry called the ministry for small and medium size enterprise to encourage small investment and create jobs

${ }^{40}$ Lambi, M.C (2001) Environmental issues problems and prospects $1^{\text {st }}$ Ed unique printer, p.10
}

population. These $60-70 \%\left[^{41}\right]$ of Cameroon's industries found in the Douala neighbourhood have brought about associated urban problems because of the dumping of industrial waste. Urban centres are poles of economic activities, Douala and Yaounde have because of their economic potentials attracted industries more than the other towns of Cameroon such as Bamenda and Bafoussam. Industrial waste contributes enormously to urban environmental degradation. Every industrial activity involves the input of raw materials through some mechanical process and the result is the finished desired economic good and some unwanted by-products or waste. If such harmful or potentially harmful industrial wastes are dumped in surface dumpsites, or in gullies, valleys or damaged basin, land pollution starts. As one commentator has observed ${ }^{42}$ the problem of management of waste commence when the environment has no more capital to transform it or store it within a given time" $\left[{ }^{43}\right]$. He went further to note that" industrialist since independence never integrated 'environmental effects' in their activities. They do not bother about the waste produce let alone the way of managing it" $\left[{ }^{44}\right]$. This is why we have industrial waste land pollution in Cameroon. For example, the industrial Zone of Bassa- Douala which contains Agro-industrial ,chemical, woods processing among others produces all kinds of waste .They do not provide necessary and adequate structures to manage these waste products $\left[{ }^{45}\right]$ it is because of this that a lot of waste is simply dumped in the environment causing land pollution. It is worthy of note that very few industries in Cameroon treat their effluent before dumping it in water or on land. The environmental code states that "waste shall be treat in an ecologically-rational manner to eliminate or curb their harmful effects on human, natural resources, the faun and flora and on the quality of the environment in general [ $\left.{ }^{46}\right]$ It is the duty of the Ministry of Environment, Nature Protection and Sustainable Development to ensure that this provision as implemented $^{47}$ In SCAN EQUIP $v$ MINEF [ $\left.{ }^{48}\right]$ a

\footnotetext{
${ }^{41}$ Ibid, p. 15

${ }^{42}$ Jouchim Ndi Odoumu is an environnementaliste working with an NGO call "le centre pour l'environment et le développement"(CED).

43 "Déchet. Population et Cie" les cahiers de mutations (May 2005) vol. 019, p.5

44 "ibid

${ }^{45}$ In Bassa-Douala, used water, all liquid effluent, used cartoons, plastics, waste of iron or glass, empty packages paper and all other types of waste are conferred or left to companies which are less specialised in clearing or treating of industrial waste or if specialised they do not have equipment. For more on this see "le Cameroun dans les Dechets Industriels", le cahiers de mutation, (may 2005) vol.029, p.5. ${ }^{46}$ Section 42

${ }^{47}$ The reason of non implementation include corruption, fear lack of complete text of application, instability of Laws, almost monolingual nature of laws, legal infrastructure, jurisdictional issues, the complexity and cost of litigation, locus standi inadequate qualified Judicial personnel ,overlapping of competence among many other.
} 
company based in Douala, was noted for dumping its waste into nature. It was warned on several occasions but it refused to heed to this warning. In 2002 MINEF sued them in the Court of First Instance in Douala for refusing to stop the pollution. After serious investigation the Court found that they had violated section 29 of the environmental code and was levied a fine of 2.800.000frs as penalty according to section 82 of the code $\left[{ }^{49}\right]$. It is discerned that the fine is too paltry to deter a big company of that calibre from polluting the environment. The amount can be paid with ease by any big company. This derisory fine levied on big companies in Cameroon who dump waste indiscriminately and without treating it has increase the dumping of waste any how and anywhere by companies. But if the quantum of damages levied is huge most companies will treat their waste before dumping and will equally dispose of it in an environmental friendly manner.

It should be emphasised here that industrial waste is equally a problem in Cameroon because some industries do not respect the environmental code. Section 43(1) of the code makes it clear that, any person who produces waste shall eliminate it $\left[{ }^{50}\right]$.

Environmental protection and management are not the pre-occupation of industrial promoters and investors who tend to look only towards the economic benefit of their activities as was seen in the case of MINEF $v$ Cameroon railway corporation (CAMRAIL) $\left[{ }^{51}\right]$.

Furthermore, this situation of industrial effluent is aggravated where the available technologies of waste treatment are unadoptable to the Cameroonian context. The inadaptability of these technologies to local needs arises from the lack quantitative and qualitative national expertise and inadequate industrial planning and investment. This inadequate industrial planning is as a result of the fact that the industrial zones development and management authority (MAGZI) $\left[{ }^{52}\right]$ is not doing the job assigned to it $\left[{ }^{53}\right]$.

\footnotetext{
${ }^{48}$ Case No. 90/TP/DLA/ march 2002 (unreported)

${ }^{49}$ See also the case of United Transport Africa (UTA) Cameroon S.A v MINEP (Unreported)

${ }^{50}$ It states that " any person who producers or owns waste shall eliminate or recycle it, or has it eliminates or recycled in plant authorised by the administration in charge of classified establishment, after the obligatory opinion if the administration in charge of the environment"

${ }^{51}$ Case No20/TPI/DLA 12 April 2003 (unreported). In that case CAMRAIL'S coaches derailed and fell at Badjob $15 \mathrm{~km}$ from Esseka. Hydrocarbon come out and polluted the land on which they stood. MINEF asked CAMRIAL to pay a fine of 2500.00frs and to clean and rehabilitate the affected area.

${ }^{52}$ Mission d'aménagements et de gestion des zone industriel

${ }^{53}$ By a 1971 decree No 71/DF-95 laying down the creation of an industrial zone MAGZI is charged with the duty of modification and management of industrial zones in the whole
}

The Ministry of the Environment, Nature Protection and Sustainable Development (MINEDEP)

This ministry was created in 2004 by a presidential decree $\left[{ }^{54}\right]$ organising the government. MINEDEP is an overseer. It acts as a watchdog. It oversees the activities of other ministries which have environmental issues to manage $\left[{ }^{55}\right]$. MINEDEP is also enjoined to send out its workers to all industries to make sure that their working milieu is clean and bacterial free. Furthermore, these controllers have as duty to insist that industries should use raw materials which do not pollute the environment and can easily be cleared or if they do, that the impact should be mitigated.

Lastly, it ensures that any individual or corporate body which breaks any law regulating the environment should be brought to book. This herculean task assigned to MINEDEP is not efficiently executed for a number of reasons. The first major problem of MINEDEP is that it is under-staffed. Most Regional Delegations have only a secretary and one $\left[{ }^{56}\right]$ worker. This makes it difficult for these workers to perform their duties well. This problem is exacerbated by the near absence of capacity building workshops for the staff. The second reason is that of lack of finance. The e ministry in question does not have adequate finances to execute the assignment given to it. The main reason being that, it has one of the smallest budgetary allocation among other ministries $\left[{ }^{57}\right]$. This makes it difficult for MINEDP to employ and train more

of the Republic of Cameroon. These zone which should be well-chosen should function or operate without pollution (nuisance) in general and the company in particular. Unfortunately this has not been successful. For example the Bassa and Banaberri regions earmarked for industries have been surrounded by houses which in away encourage pollution because the land surrounding industrial land has been taken up by private residence, most factories find if difficult to dispose their waste. This leads to pollution in Yaounde, part of the region earmarked as an industrial zone has been taken up by private residence (for example, part of the Mvan neighbourhood which has been occupied by private residence houses and equally Ndi Samba university. This problem is continues because the councils are not regularly pulling down or demolishing theses houses built in this region may be because of lack of the will to do so or the Mayor might have been corrupted.

${ }^{54}$ Decree No 2004/320 of $8^{\text {th }}$ December 2004 organising the government.

${ }_{55}$ AKo JA (2010) The implementation of International Environmental law policies in Cameroon. The case of Environmental impact Assessment. Unpublished DEA Dissertation of the university of Yaoundé IISoa p. 29

${ }^{56}$ For example the Divisional delegation of MINEDEP in Kribi has just the secretary and a single worker. Information gotten from the secretary General of that Ministry in 2012.

${ }^{57}$ The budget allocated to MINEDEP for the year 2011 is only 8 billion 806 million CFA francs see Cameroon tribune No 9505/5706 $36^{\text {th }}$ year Monday 28 December 2010 website: www. Cameroon tribune. com 
controllers. Even the few it has, it still finds it difficult to send them out on the mission already discussed.

\section{Effects of Waste}

Waste not well cleared or treated has many ramifications. Some of them will be discussed.

\section{On The Environment}

In Cameroon waste dumped carelessly causes lots of problems on the environment. Plastic bags used in wrapping food staff in the market are thrown carelessly on the soil. Most of them do not decompose fast. It is an unattractive site when these bags litter the environment especially in market areas $\left[{ }^{58}\right]$.

Furthermore, the waste dumped on land makes the soil infertile $\left[{ }^{59}\right]$; a case in point is the region at PK 10 where waste cleared from the Douala urban centre is dumped pollutes the environment. The decomposition of these waste release acids that kill soil organism and also destroy the fertility of the soil.

Water pollution is also a common act that results from waste dump on land. When waste is dumped on land and rain falls on it the waste decomposes. The decomposed waste is washed into streams and rivers, some into gutters which block them. The consequence is a flood. The is why floods are a regular occurrence in Yaoundé, Douala, Bafoussam, and Bamenda.

Most of the quarries in Cameroon are polluted because of the excavation exercise carried out on them. The remaining land is waste land which cannot support any living creature $\left[{ }^{60}\right]$. Water pollution is also a common act that results from waste dumped on land when waste is dumped on land and rain falls on it the waste decomposes. The decomposed waste is washed into streams and rivers, some into gutters which block them. The consequence is a flood. That is why floods are a regular occurrence in Yaoundé, Douala, Bamenda and Bafoussam.

The effect of oil deposited on land can be very severe and persistent sometimes lasting unaltered for

\footnotetext{
${ }^{58}$ An example is the Njombe region where the blue plastic papers used by CDC to protect bananas from insects, birds and insedticides spraying litters the whole region. A walk across the region reveals that the area occupied by the CDC planation and its environment is blue because of these plastic papers. Most people in this region use them for parcelling meat, fruits, and groundnut without being aware that these plastic bags are toxic. For more on this see "A chacun son bout....." Dossier " Economie et Ecolgies" ECOVOX No. 18 Avril- June 1999 p.2

${ }^{59}$ An example is where refuse is dumped at the Nkilfolou neighbourhood in Yaoundé.

${ }^{60} \mathrm{An}$ example is the Agnon 11 quarry found at Mbankomo in the centre region.
}

decades. The consequences are usually enormous on the ecosystem

Plastic bags' waste litters streets and the grass while some float on streams. All these gives an unattractive sight of grass, land and stream $\left[{ }^{61}\right]$. Some of these plastic bags which float on stream lead to the clogging of the water channel. The end result are floods especially when it rains heavily. This is one of the causes of floods in the Douala and Yaoundé urban centres $\left[{ }^{62}\right]$. Of the 6 million tons of waste produce daily in the entire republic, $60 \%$ is composed od plastic bags $\left[{ }^{63}\right]$.

\section{Effects on Man}

Poor waste management is one of the major causes of human diseases the world over the health implication of poor waste management in the society are obvious, because poor waste management destroy the physical, mental and social well being of man. When waste is not well managed and treated mosquitoes, bacterial and vectors grow on the waste. That is why there is a high rate of malaria attack in Douala for instance. Cockroaches ${ }^{64}$ and flies are insects that thrive mostly on waste. Once the environment is not clean their reproduction also increases.

\section{Effects on Animals}

Poor waste disposal has effects on animals. Heavy metals on land can be taken up by grazing animals and this enters their food chain. When they are taken up by animals, diseases such as cancer will be the end result. This will lead to the reduction of animal population. Plastic bags used to tie goods pollute the environment in Cameroon especially in market areas. Some of them adhere to the soil, while some are blown by the wind on to the tree branches. These plastics bags are very dangerous to animals when eaten by them because they do not digest. The plastic remains in the gut of the animal and later kill it.

Land that is covered by waste is very dangerous to animals because the ground is their habitat. When this habitat is polluted it becomes dangerous for the animals because moving on and living on the land will bring them in contact with the polluted area which can result to death.

\section{Effects on Plants}

Plants need a conducive environment to grow. Land polluted by poor waste management destroys the humus of the soil and thus hampers plant growth. Plants that grow on polluted land take up heavy metal that

\footnotetext{
${ }^{61}$ This typical of what obtains in big towns of Cameroon.

${ }^{62}$ Cameroon tribune No. $8836 / 503533^{\text {rd }}$ year Tuesday $23^{\text {rd }}$ April 2007, p. 13

${ }^{63} \mathrm{ibid}$

${ }^{64}$ Cockroaches transmit leprosy while flies transmit a host of their illnesses.
} 
destroy or kill them. That is why most plants that grow on waste polluted land die shortly after shooting up.

Oil spillage or throwing of waste oil on the ground pollutes it. This affects plant growth. This explains why most areas surrounding petrol stations and garage do not have any vegetation. Oil spillage should be treated as a serious problem for it pollutes land for a long time. The Ogoni people's problem in the federal Republic of Nigeria $\left[{ }^{65}\right]$ is attracting a lot of international attention because of the environmental impact of the oil spill on the land and crops. The oil spill does not only affect plants and soil but also wildlife.

\section{Waste Disposal Method}

Waste management is different from waste disposal. Waste management is the collection, transportation, recycling and elimination of waste including the monitoring of disposal sites $\left[{ }^{66}\right]$. On the other hand waste disposal is defined by section 4 (1) of the code as "all the operations comprising the collection, transportation, storage and processing necessary for the recuperation of useful materials or energy and for their recycling or any deposit or discharge of any product in appropriate areas under conditions geared towards avoiding harmful substances and environmental degradation”.

Cameroon produces about 2.000 tons of waste daily, 660.000 monthly and 7.892.000 tons yearly $\left[{ }^{67}\right]$. This section will examine some historic methods of waste disposal as well as some future options.

\section{Open Dumps}

Until recently, the disposal of municipal solid waste did not attract much public attention in Cameroon. Historically, the favoured means of disposal was simply to dump solid wastes outside of the village limits $\left[{ }^{68}\right]$. To minimise the volume of the waste, the dump was often burned. Unfortunately, this method is still being used in remote or sparsely populated areas in Cameroon $\left[{ }^{69}\right]$. As values changed, more emphases were placed on the environment and quality of life. Simply dumping and burning our waste is no longer an acceptable practice from an environmental or health perspective. For many people in Cameroon, the way to dispose of waste is to simply drop it at some place which is contrary to section 50(2) of the environmental

\footnotetext{
${ }^{65} \mathrm{~A}$ case in point is the lack of vegetation on the quarry area at Namayos-Mbankomo in the Centre Region.

${ }^{66}$ See Olusi J (1981) "Human Health Hazards Association with petroleum relates pollution in the preceding's of the 1981 international seminar on the petroleum industries and the Nigerian Environment.

${ }^{67}$ Section 4(q) of the 1996 environnemental code.

${ }^{68}$ Report sur l'état de la protection civil au Cameroun (2005) cap sur la sauvegarde de notre cadre de vie p. 196

69 Jackson, M.H (1989) Environmental Health Reference
} Book. London, Butterworth Heinemann, p.89. code. The section states unambiguously that "the dumping of waste on public land shall be strictly prohibited, including public maritime land such as defined by the law in force" In spite of this provision open unregulated dumps are still the predominant method of waste disposal in Cameroon, notwithstanding the provision of section $47(1)$ of the code $\left[{ }^{70}\right]$. It is important to not here that if the above cited section is strictly enforced in Cameroon open dumps will not exist or if they have to exist they will respect the basic norms of open dumps. In Cameroon open dump lands are still available but (open dumps which are not authorised) are not permitted as section 50(2) of the code states.

\section{Landfill}

It is the most common method of waste management in most part of the world including Cameroon. It involves the digging of a hole in the ground, and filling it with rubbish after this filling the hole is then covered and comprised. Landfall operations are required to compact the refuse and cover it with a layer of dirt. This method helps control pollution. The problem of landfall is leaching because overtime, the liquid seeps through the landfill and takes with it harmful chemicals from the waste, if it rots, it produces methane gas and carbon (iv) oxide.

In Cameroon landfills have been legalised by the environmental code so long as the person doing it obtains an authorisation from a competent authority $\left[{ }^{71}\right]$ as provided by section 51(1) of the code $\left[{ }^{72}\right]$.

The wordings of subsection (2) of section 51 of the code reveals that where a person landfills without obtaining permission, he shall excavate the buried waste or be asked to pay a charge by a competent administrative authority. The sole aim of this section is to reduce or prevent as much as possible the negative effects of the environment form the land filling of waste and to limit emissions of methane gas by reducing the amount of biodegradable waste going to landfills to achieve this, protection of the environment should continue during the whole life cycle of a landfill site, including when it has stopped receiving. Land filling is practiced in Cameroon by HYSACAM. It does this only in Yaounde. The environmental concerns surrounding

\footnotetext{
${ }^{70}$ ibid

${ }^{71}$ The section state that "the person producing or processing waste shall eliminate the said waste under the join authorization and monitoring of the administration in charge of the environment and mines respectively, in accordance with prescription laid down by regulation" Subsection (2) further provides that "waste shall be discharged into dumps that are periodically inspected and which respected and which respect the minimum technical norms of dump management"

${ }^{72}$ This authorization is issued by the minister in charge of the Environment, nature protection and sustainable development as stipulated by article 3(1) of the ministerial arrête No 001/MINEPDED of $5^{\text {th }}$ October 2012 laying down the condition to obtain permission on waste management.
} 
landfills include the production of land fill gases formed during the decomposition of biodegradable waste. These gases contribute to climate change. It is because of these effects that section 51(1) was enshrined in the code to govern landfill. Even though landfill is still alien in Cameroon it should be discouraged because of the problem associated with it. Instead recycling and incineration are the primary methods. These are the methods which should be encouraged in Cameroon. HYSACAM does not treat before it is put into a landfill .From the foregoing it is discerned that the environmental code has many lacunae. It is therefore submitted that Section 51 and 52 of the environmental code should be revised and the treatment of waste before land filling should be made compulsory $\mathrm{n}$ order to reduce the effects of land filing.

\section{Incineration}

Incineration means "burn to ashes or burning up of rubbish either in an incinerator or open space $\left[{ }^{73}\right]$. Land filling is still the disposal method for the majority of municipal waste in the world $\left[{ }^{74}\right]$. Faced with growing piles of garbage and a lack of available landfills at any price public official are however looking for other disposal methods. The method which they frequently turn to is burning .Incineration is not very welcome today because of the aesthetic concerns, such as foul odours, noxious gases and gritty smoke. Today, about 16percent of the municipal solid waste in the US is incinerated Canada incinerates about 8 per cent $\left[{ }^{75}\right]$, Cameroon incinerates 2 percent $\left[{ }^{76}\right]$. Incineration leads to air pollution .The dust or residue of the incinerated domestic waste sometimes contains dioxin. Dioxin has a negative impact on the environment and man $\left[{ }^{77}\right]$. In Cameroon incineration is common. It is carried out by individual and institutions such as offices and hospitals. However with the hiring of HYSACAM $\left[{ }^{78}\right]$ the act is now reduced in the towns where the company is found. In towns $\left[{ }^{79}\right]$ where the company does exist,

\footnotetext{
${ }^{73}$ It states that waste shall only buried in the sub soil with the prior joint authorisation of the competent administrations which shall lay down the technical prescriptions and special rules to observe" subsection (2) goes on to state as follows that " the burial of waste without the authorisation provided for in sub-paragraph (1) of the article shall lead to an excavation of the waste by the person who buried it or after a charge to pay from the competent administration in collaborationWith the other administration concerned.

${ }^{74}$ Hornby , A S (ed) (2005( Oxford Advanced Learners Dictionary of current English $7^{\text {th }}$ Ed Oxford University press p. 430

${ }^{75}$ Cunningham, W.P and Woodworth is (2001) Environmental science $6^{\text {th }}$ Ed McGraw Hill Co. Press.

${ }^{76}$ BOSANGI, Le Magazine trimestriel de la proprete-Avril/ Mai/Juin 2006 No.006 ,p.29

${ }^{77}$ Ibid. p. 530

78 BOSANGI. Le magazine trimestriel de la propretéAvril/Mai/Juin 2006 No.006 P 28

${ }^{79} \mathrm{On}$ man it affects the nervous system destroys the immune system, alters the reproductive system and promotes body and lung cancer when air containing this dioxin is inhaled. On the
}

incineration is carried out especially in the dry season. The residue is not deposed of as is the case in most developed countries but left at the site and is normally disposed of by wind and rain water. When this happens it leads to air, water and land pollution with all its effects. The Cameroon Government being conscious of the consequences of incineration responded by enacting section $49\left[{ }^{80}\right]$ of the code which forbids incineration. An interpretation of this section indicates that it forbids incineration only on water and not on land despite the effects mentioned in the foregone. It is visible here that there is a lacuna in the environmental code with regards to incineration. It there means that if a person or institution incinerates on land, he or she will go unpunished. It is said that the environmental code of Cameroon is based on international norms but this is not true because incineration has been banned in many European countries $\left[{ }^{81}\right]$. However it is suggested that section 49 of the code should be revised and let incineration on land be forbidden. Note only revising it but the revised section should be enforced because one of the major problems of Cameroon is the lack of enforcement of Laws.

\section{Recycling}

The term "recycling" has two meaning in common usage. Sometimes the term recycling is used when we really mean "re-using" something such as refillable beverage containers. In term of solid waste management, however, recycling is the reprocessing of discarded materials into new, useful products $\left[{ }^{82}\right]$ the environmental code of Cameroon does not define it. It only mentions it in section 45(1) and 50(1).

At first sight, the concept of recycling waste and using it again is environmentally attractive. To eliminate waste must be a sound manoeuvre and to make something out of what would have been thrown away, appeals to a sense of ethnic as Boyne affirms $\left[{ }^{83}\right]$. It appeals to the "waste not, want not" ethic $\left[{ }^{84}\right]$ in spite of this charm, recycling has its own problems. For example, the waste has to be claimed and then sort out first into constituent parts before the actual recycling

environment it destroys the soil, sub soil, the grass surface, water and underground water when rainfalls and dissolves it.

${ }^{80}$ It is a garbage colleting company hired by urban councils in Cameroon.

${ }^{81}$ See Directive 2000/76/EC on the Incineration of waste

${ }^{82} \mathrm{In}$ a towns such as Bamenda, Kumba and Banso, domestic waste is cleared by their urban council's trucks when the trucks brakes down, the waste is burnt. This act was very prevalent in the Yaoundé -urban town in the late 1990s because of the financial crises which hit the urban council then.

${ }^{83}$ Waste immersion, incineration or elimination by any procedure in the continental and or maritime water under Cameroonian jurisdiction shall be strictly prohibited, duly taking into account the international commitment as Cameroon.

${ }^{84}$ See directive $200 / 76 / \mathrm{EC}$ on the incineration of waste. 
process can start. In the US the environmental protection Act of $1990\left[{ }^{85}\right]$ states that "the government should use finance as a means to encourage the use of recycling as a method of waste deposal" . The idea of using financial instrument to encourage recycling is supported by Environmentalist $\left[{ }^{86}\right]$. "Friends of the Earth" $\left[{ }^{87}\right]$ for example, encourage such a method but emphasised that it should only be seen as one way to encourage a reduction on the overall quantity of waste produced.

The idea of recycling is either unknown or less developed in some isolated cases in the big cites of Cameroon $\left[{ }^{88}\right]$. Quite often, the three different types of urban solid waste are found mixed up and manage together without any distinction $\left[{ }^{89}\right]$.

However, recycling can be encouraged in Cameroon as is done in other countries such as Germany where householders are provided with different coloured bags for different types of waste. Furthermore, financial, instruments can be used to encourage recycling in Cameroon as is done in the UK.

A provision for the recycling of waste is found in sections 43(1) $\left[{ }^{90}\right]$ and 50(1) $\left[{ }^{91}\right]$ of the environmental code of Cameroon. A reading of the two sections cited above discloses that recycling is not only mentioned in this code but is mandatory as one of the options to manage waste. "Shall mentioned in the two sections means obligatory to the producer or owner of waste whether he is willy-nilly. Despite this recycling is not fully carried out in Cameroon because of a number of reason namely: almost lack of machines to do recycling, few trained personnel, lack of enough finance to finance the operation, waste is jumbled up in a dust bin without selecting it and lastly an authorisation to so must be obtained from the minister in charged of Environment, nature protection and sustainable development as the prime ministerial Decree of $2012\left[{ }^{92}\right]$ provides. This condition discourages some people who intent to do so because of the hurdles they will go through to obtain the

${ }^{85}$ Thornton J and Beckwith, S (2004) Environmental law $2^{\text {nd }}$ Ed sweet and Maxwell p. 190.

${ }^{86}$ Boyn. G.A (1998) " The Determinant of variation on local service contracting Garbage in Garbage out" 34(1) urban Affair Review 150-63 pp 101-116

${ }^{87}$ Ibid

${ }^{88}$ Section 52

${ }^{89} \mathrm{Heftz}, \mathrm{A}$ and warner, $\mathrm{M}(2004)$ privatisation and its Reverse :Explaining the dynamics of the Governmental contracting process 14(2) Journal of public Administration theory: pp 171-90.

${ }^{90}$ It is an environmental protection NGO based in the UK.

${ }^{91}$ Ma'a M.A (2006) "le Gestion des Eaux useses en Hotelier et Tourime Durable: cas de l'Hotel de Deputes » unpublished maitaise memoir of the department od Geography university of Yaounde I p. 76.

${ }^{92}$ Mbedoum, m (1990) le Gestion des ordure Managere dans la nylon de Douala. Unpublished maitrise memoir of the department of Geography. University of Yaoundé 1,p.42 permission. Recycling is usually a better alternative to either dumping or burning of waste. It saves money, raw materials, land space and equally reduces pollution $\left[{ }^{93}\right]$.

\section{Packaging Waste}

In 1994 the EC enacted a Directive $\left[{ }^{94}\right]$ on packaging waste $\left[{ }^{95}\right]$ which is one of the first pieces of legislation to regulate a specific waste stream. The Directive has three main objectives namely:

- To reduce the effect of packaging on the environment

- To coordinate national measures in order to prevent distortions to competition and

- To ensure the free movement of packaging goods

Reducing the effect of packaging on the environment is to be achieved by limiting the disposal of packaging waste, and requiring instead, that it should be re-used or recovered. "Packaging" is defined widely to mean all products made of any material which is used for the "containment, protection, handling delivery and presentation of goods $\left[{ }^{96}\right]$. Packaging which does not comply with certain "containment, protection handling delivery and presentation of good $\left[{ }^{97}\right]$ packaging which does not comply with certain "essential requirement" relating to its "composition are re-usable and recoverable nature" cannot be placed on the market. Member states are required to develop national standards for the composition re-usable nature of packaging.

In the central African sub-region where Cameroon belongs, there is no sub-regional instrument as regards packaging. The environmental code of Cameroon dose not distinguish between different types of waste but merely discusses waste management generally. This is a lacuna inherent in the

\footnotetext{
${ }^{93}$ The section states that "any person who produces or own waste, shall eliminate or recycle it, or have it eliminated or recycled in plans authorised by the administration in charge of classified establishment, after the obligatory opinion of the administration in charge of the environment. Besides, the person shall inform the public of the effects of waste production owning, elimination or recycling on the environment and public health pending the rules of confidentiality and the measure intended to prevent or compensate its negative effects"

94 The section provides that "the obligation of general maintenance which the public land dealers are subject to shall include those to eliminate, cause to be eliminated, or recycle waste contained in the land"

${ }^{96}$ Article 27 of Prime ministerial Decree No. 2012/2809 PM of $26^{\text {th }}$ September 2012 laying down the conditions to collect, store, transport, recycle, treatment and disposal of waste.

${ }^{97}$ Another benefit of recycling is that it could drastically cut our waste volumes and reduce the pressure on disposal system.
} 
Environmental code this explains why in Cameroon there is a lot of waste resulting from packaging.

\section{End- Of-Life Vehicles}

Every year, disposal of vehicles at the end of their use generates between 8 to 9 million tons of waste in the European Community $\left[{ }^{98}\right]$. The directive $\left[{ }^{99}\right]$ on end -of life vehicles aims to reduce the amount of waste and therefore the adverse environmental impacts, resulting from the disposal of vehicles. No regional instrument of this nature exists in the central African region where Cameroon is found. Furthermore, the environmental code of Cameroon does not contain any provision on end -of-life vehicles.

End-of-life vehicles are dumped everywhere in Cameroon. Sometimes in garages, roads sides and even at the owner's abode. Some of the end-of-life vehicles are collected by councils to waste dumpsites but it is rare exercise in Cameroon. The consequences of this are immense. For instance, they pollute the land where they are abandon. Section 48(1) of the code states clearly that, any producer of waste who dumps, abandoned or processed it in violation of this section should be eliminated by the person who has the police power at the expenses of the producer. Sub section (2) states further that, "the administration shall oblige the producer to deposit to a public accountant a sum corresponding to the cost of the work to be done. In spite of these sections, abandoned old vehicles are found everywhere. The council whose duty is to clean the town is not doing its job. Even where it does, it does not sanction the producer of the waste as section 48(2) provides. Secondly, the law is not very clear with regards to end-of -life vehicles. In the UK $\left[{ }^{100}\right]$ unlike in Cameroon, there is a regulation specially enacted for end-of -life vehicles $\left[{ }^{101}\right]$. Lastly, the central African sub region (CEMAC) does not have an instrument that regulates end-of-life vehicles.

It is propose that the central African region should also enact an international regional instrument that governs end-of -life vehicles as obtains in the $\mathrm{E}$ From the elaborate advantages discussed it is seen that if some of its provision are adumbrated in the Cameroon environmental code it will go a long way to reduce pollution caused by end-of -life vehicles.

\footnotetext{
${ }^{98}$ Directive No.94/62/EC

${ }^{99}$ European parliament and council directive 94/EC of Dec. $20^{\text {th }} 1994$ on packaging and packaging waste DJL 365 , 3112,1994 p.10

100 Lawrence D and Lee, R (2003) "Permitting uncertainty.Occupiers, and responsibility for remediation" 33 modern law review, P.262.

${ }^{101}$ This explains why there is a lot of waste resulting from packaging because no Directive exist as in the EC insisting that packaging which does not comply with certain "essential requirements" relating to "its composition and re-usable nature" cannot or should not be placed on the market.
}

\section{Composting}

Municipal composting is another source od reduction technique that could have substantial impact on the environment pressed for landfill space, many cites have banned yard waste from municipal garbage. Rather than burn this valuable organic material they are turning it into a useful product through composting .Building a composite pile is a popular practice with many home gardener because it turns waste into a useful soil additive. Home compost pile is an easy and inexpensive way to dispose of organic waste in an interesting and friendly manner. Compositing is gaining popularity because it is cost effective and substantially extends a land fill's useful life. Large-scale municipal or industrial compost facilities have some of the same public relations and sitting problems as incineration and land fills. Neighbours complain of noise, odour, vermin and increased traffic from poorly run facilities. HYSACAM practice compositing at Nkolfoulou, where the municipal waste collected in the Yaoundé urban town is dumped. The advantages of composting in the Nkolfoulou waste dump site are the same to those which have already been discussed. Individuals and institutions such as schools equally practice it. The Environmental code of Cameroon is silent on it. It is worthy to note that only organic waste can be composed non-biodegradable waste cannot.

\section{Demanufacturing}

Demanufacturing refers to the disassembly and recycling of obsolete consumer products, such as television sets, personal computers, refrigerator, washing machines and air conditions. It is a good way to recover valuable materials. In Cameroon, many people use TV Sets for more than 15year especially if they were bought new. Most of the electronic appliances in Cameroon quickly become obsolete because, especially if they were bought or imported as second hand goods from Europe. Their life span, therefore, becomes extremely short by the time they are put into use in most African countries including Cameroon. They therefore very quietly end up as waste. The Ministerial Arrête $\left[{ }^{102}\right]$ governing the importation of second-hand goods including cars does not stipulate the maximum age of second hand goods to be imported into Cameroon. Many of these consumer products contain toxins that must be kept out of the environment. For example, older refrigerator and air conditions have chlorofluorocarbons (CFC) that destroy stratospheric ozone layer and cannot be released into the air. For both reasons, it pays to recycle them $\left[{ }^{103}\right]$. It should be noted here that recycling of the above-mentioned articles is not done in Cameroon for the main reason that Cameroon only imports and does not produce or manufacture them. It is therefore proposed that Cameroon should reduce the importation of these

\footnotetext{
${ }^{102}$ Arrête No. 010/MINDIC du 12 Avril 1991 déterminante les Conditions d'Importation des Véhiculés d'Occasion.

${ }^{103}$ Cunningham, P.W. and Sago, W.B op. cit. p. 533.
} 
second hand goods and encourage the importation of new goods. This reduction can be done by strictly implementing Section 22 of the Ministerial Arête [ $\left.{ }^{104}\right]$ which states that importers of second hand goods should obtain an authorisation to do so.

\section{Re-use}

"Re-use" means using something again. The environmental Code of Cameroon is silent on re-use. Where possible, re-use is even preferable to recycling as it does not involve the cost and energy of transforming a used good into a new product or thing. Auto parts are regularly sold from junk yards especially for older car models. Some communities sort and reuse a variety of materials received in their dumps $\left[{ }^{105}\right]$. In all towns of Cameroon, glass and plastic bottles are routinely returned to beverage producers for washing and refilling. The reusable, refillable bottle is a most efficient beverage container. This is better for the environment than re-melting and more profitable for local communities. In my opinion, the practice of reusing ought to be encouraged in Cameroon because it does not only make economic sense, but is equally environmentally friendly.

\section{Producing less waste}

The most fundamental way to reduce waste is to prevent it from ever becoming waste in the first place. What is better that re-suing materials? Generating less waste in the first place is a major answer. Examples of sources reduction are using less material when making a product or converting it from having packaging materials to light weight ones. This issue of source reduction is not regulated by the Environmental Code of Cameroon. Cameroonians can reduce the production of waste by buying food that comes with less packaging, wash and re-use bottles, aluminium foils, plastic bags etc. for their own personal use. Excess packaging of food and consumer products is one of Cameroon's sources of unnecessary waste.

\section{The Control of Waste}

The waste regime in Cameroon does not distinguish between controlled waste and special waste as done in some countries. It only distinguishes industrial waste from normal waste in Section 47(3) of the Environmental Code. The section states that: "special industrial waste considered dangerous on account of their properties shall not be dumped in stock plants receiving other categories of wastes." The management of wastes in Cameroon is entrusted to Urban Councils as Section 16 of the Law Regulating Councils states $\left[{ }^{106}\right]$. This function of eliminating

\footnotetext{
${ }^{104}$ Arrete No. 061/MINEPDED of 15 October 1202 Laying down Conditions to Obtain a permit to manage waste

105 Purdue, M. (1990) "Defining Waste" Journal of Environmental Law (JEL), Vol. 22, No. 2, p. 259

${ }^{106}$ Law No. 2004/018 of 22nd July Laying Down Rules Applicable to Councils.
}

household waste by the Council is spelt out in Section 46 of the Environmental Code. With the growing of domestic waste in big cities $\left[{ }^{107}\right]$, urban Councils had no choice but to grant the cleaning and collection of waste to a private company called HYSACAM $\left[{ }^{108}\right]$. The licence to collect and deposit waste by HYSACAM is issued by the Urban Councils as provided by the 2004 Law governing Councils. Section 17 of the above cited law states that, it is the Council which gives an authorisation to a garbage collecting company where to deposit collected wastes $\left[{ }^{109}\right]$.

Conditions could be attached to the disposal licence under the 2004 law, but the effects of these conditions are limited by the courts. In Cameroon, the Ministerial Arrête provides that, a licence is given to a garbage collecting company for 5 years renewable. It does not mention the maximum number of renewals, which means it can be renewed as many times as possible. A problem is posed here because if the company to which the authorisation has been given to collect garbage is not doing well its contract may not be terminated easily. But if the time of renewal is spelt out or limited, it will make the company to sit up. Again, the contract will easily be terminated. It is therefore, proposed here that the number of renewal periods should be well spelt out.

\section{The Duty of Care}

It is an important and novel form of liability for producers and handlers of wastes. Although the principle or notion of duty of care is not found in the Environmental Code of Cameroon, the concept if however, of general application where appropriate in Cameroon. Since it is not expressly excluded by statute in the circumstance (that is, in the circumstance of environmental law).

The term "duty of care" is a familiar one derived from the law of Torts and the famous case of Donoghue $v$ Stevenson $\left[{ }^{110}\right]$. It is a common law principle which has been adopted by many common law countries. The central idea of the common law principle of the duty of care is that a person owes a duty to take care, not to injure others by his acts or omissions. When the duty of care principle was first introduced, it was understood as extending liability from "cradle to grave" in fact, the duty of the waste producer is not as extensive as that. Instead, it is designed to satisfy the European ideology as the environment that the polluter pays. The producer of waste is responsible for the

\footnotetext{
${ }^{107}$ Such as Douala, Yaoundé, and Bafoussam.

${ }^{108}$ The functions of this company are to collects and treats household wastes and equally to sweep and mop streets.

${ }^{109}$ In Yaounde there is the Nkolfolou neighborhood, in Douala we have the PK 10 and in Bafouassam, the Government Bilingual High School and river mezam neighborhood among others.

${ }^{110}(1932)$ AC 562, 580
} 
proper disposal of the waste $\left[{ }^{111}\right]$. This means that, the producer must ensure it is transferred to a responsible carrier. The producer can no longer escape liability simply by passing the waste onto anyone else who could include the fly-tipper or HYSACAM in the case of Cameroon. The aim of the duty of care is

- To prevent the commitment of one of the statutory offences;

- To prevent the escape of waste; and

- To make sure waste is transferred to an authorised person.

Therefore, the provision focuses on the control of waste prior to disposal and the steps to be taken on disposal. Liability after transfer will be limited to failing to take reasonable steps to detect and prevent breaches by the next person in the chain. It is likely, therefore, that a waste producer, who complies with the rules of guidance on transferring waste, will be considered to have taken such reasonable steps. The duty is imposed on all who import, produce, carry, treat or dispose of controlled wastes $\left[{ }^{112}\right]$. This includes special wastes

In summary, the preceding discussion suggests that the main function of the duty of care is to encourage responsible behaviour and the development of appropriate management systems for the, storage, transfer and monitoring of waste, rather than punish wrongdoing.

\section{CONCLUSION}

It is clear from the foregoing that national rules relating to waste are with a few exceptions aimed at regulating the disposal of waste rather than preventing its generation. Furthermore, the problem arising from waste management is not only that there are not enough laws but rather that even the available ones are not well enforced.

It is equally visible that the main problems facing waste management in Cameroon are that most industries have a poor waste management standard.

Economic consideration seems to be the primordial consideration of industries rather than environmental consideration as enshrine in the legislation.

Regulating disposals has a certain logic: there is some evidence to suggest that a tightening of international and national regulations will increase costs and that this might act as an incentive to encourage people to generate less wastes. On the other hand, it seems clear that, limiting the avalanche of waste which is now threatening to engulf industrialised countries

${ }^{111}$ See Section 43(1) of the 1996 Environmental Code of Cameroon

${ }^{112}$ Ibid. (and will presumably follow the same path over time for developing countries) requires the development of strategist and legal rules which address the waste problem at source by preventing its generation.

It is also noted that if the activities of man are properly checked and regulated to protect and preserve the environment especially its land, water and air, then the problem associated with waste can be minimised.

From the problems raised in this paper, one may conclude that the law that regulates waste management in Cameroon is a curse but this curse can be turn to a blessing by putting forward some proposals which if adhered to will turn the curse into a blessing. We therefore propose that the quantum of damages levied on a polluter under the polluter pays principle should be stepped up for this will push waste producers to manage their waste in an environmentally friendly way.

It is also proposed that the Environmental Code of Cameroon should be revised and make it more encompassing.

Putting these recommendations and those proffered in the forgoing of this paper into practice will go along way to reduce waste production or enable producers of wastes to manage it well because the production of waste cannot be stopped except mankind will ceased to exist. 